\title{
CONTRIBUTION OF PROFESSIONAL ETHICS IN INVESTING THE EFFECT OF GOAL ORIENTATION AND TASK COMPLEXITY ON AUDIT JUDGEMENT
}

\author{
Sukandani Yuni*, Waryanto R. Bambang Dwi, Istikhoroh Siti \\ Faculty of Economics, PGRI Adi Buana University of Surabaya, Indonesia \\ ${ }^{*}$ E-mail: yuni sukandani@yahoo.com
}

\begin{abstract}
The purpose of this study was to analyze the role of professional ethics in interfering with the influence of goal orientation and the complexity of the task of audit judgement. The study sample was a public accountant who worked at the Public Accounting Firm or Kantor Akuntan Publik (KAP) in Surabaya, Indonesia. The analytical method used is path analysis. The results of the study indicate that the goal orientation and task complexity affect audit judgements directly or indirectly through professional ethics.
\end{abstract}

\section{KEY WORDS}

Audit judgement, ethics, audit quality, goal orientation, task complexity.

From various legal cases, several cases involved public accountants. For example the Enron case in 2001, which resulted in a decline in world stock prices due to loss of trust. In that case, Enron was proven to have collaborated with one of the international Big Five group professional accountants, Arthur Anderson, to do bookkeeping manipulation by boosting profits of US \$ 1 billion (Buchan, 2005). In Indonesia, several cases of violations of the accountant profession developed along with several ethical violations committed by public accountants, internal accountants, and government accountants (Machfoedz, 1999). Bachtiar (2012) revealed several examples of cases of violations of accounting ethics in Indonesia, including the involvement of 10 national KAPs in auditing bank financial reports before the 1997 crisis, inflating the capital of PT. Kimia Farma in 2001, Lippo Bank's double bookkeeping in 2002, as well as the Bakri Group's fund storage case at PT. Bank Capital Indonesia in 2010. In the financial statements as of March 31, 2010, a total of seven Bakrie Group issuers claimed to have deposited a total of Rp. 9.07 trillion in Bank Capital even though the bank stated that Bakrie Group deposits were only Rp. 2.69 trillion.

The root of the problem of accounting fraud cases is that auditors do not provide proper audit judgement $s$ when examining financial statements. An audit judgement is a measure of the quality of auditor performance. In making judgement, the auditor has an awareness that an accountability is a significant factor because his judgement will be reviewed and questioned. Judgement refers to cognitive aspects in the decision making process and reflects changes in evaluation, opinion, and attitude. Quality judgement shows how well the auditor's performance in performing his duties.

There are factors that influence the performance of an auditor in making audit judgements that are both technical and non-technical. One of these factors is individual behavior such as goal orientation and task complexity. Goal orientation is a goal preference in achieving situations, is one of the important topics in education, psychology, and organizational research literature (Payne et al., 2007). Goal orientation provides a mental framework that is used by a person to interpret and respond to situations' achievements and failures (Dweck and Leggett, 1988) and individual differences in building understanding of learning, training, and performance outcomes (Zweig and Webster, 2004).

Testing the effect of the complexity of the task on audit judgements is also important. This is because the audit task is a task that is always associated with complex problems in the company (client). Another reason why this test needs to be done is because the facilities and techniques for making financial statements are thought to have been conditioned in such a way that the auditor understands the incongruity (Bonner, 1994). 
The influence of goal orientation and complexity of the task will have a positive or negative impact on audit judgement depending on the ethics of each public accountant. The accounting profession ethics has become a very interesting issue following the disclosure of several financial scandals involving international auditors. Ethical violations will not occur if every accountant has the ability, understanding, and willingness to implement moral values adequately in his professional work (Ludigdo, 1999).

The measurement of the moral quality of accountant ethics can be formulated through understanding the Professional Code of Ethics. The ability to maintain, uphold, and carry out the values of truth and morality, such as responsibilities, integrity, acting objectively, and maintaining independence from the interests of various parties (independence), as well as being careful in carry out the profession (due care). The greater the understanding of the Professional Code of Ethics, the less likely the accountant is to commit fraud so that the higher quality of the audit is given.

This study aims to analyze the role of professional ethics in interfering with the influence of goal orientation and the complexity of the task of audit judgement. The sample used is a public accountant who works at the Public Accountant Office (KAP) in Surabaya. This research is expected to contribute to the literature regarding audit judgement.

\section{LITERATURE REVIEW}

Goal orientation. Goal orientation is a mental framework of how individuals interpret and respond to situations/events they face (Dweck and Legget, 1988). Specifically there are two kinds of goal orientation, namely the orientation of the performance goals and the learning goals. The goal orientation in achieving achievement is classified into two: orientation of learning objectives and orientation of performance goals (Nicholls, 1984 in Mustikawati, 2006).

Goal orientation can predict performance in the educational environment (Dweck, in Johnson et al., 2000), and research has proven that goal orientation has important implications for training and motivation in the context of the organization (Martocchio, 1994). Learning orientation and performance orientation are in one contradictory contraction. According to Johnson et al., (2000), learning orientation focuses individuals on the development and complex task strategies. One consistent research finding in motivational literature is that greater challenging goals produce higher performance than easy goals or best-done goals (Locke and Latham, 1990).

Task Complexity. Auditors are always faced with many tasks, different, and interrelated with each other. Task complexity can be defined as a function of the task itself (Wood, 1986). Task complexity is an unstructured, confusing and difficult task (Sanusi and Iskandar, 2007). Some audit tasks are considered as high complexity and difficult tasks, while others perceive them as easy tasks (Jiambalvo and Pratt, 1982). This perception raises the possibility that an audit task is difficult for someone, but may also be easy for others (Restuningdiah and Indriantoro, 2000). Furthermore, Restuningdiah and Indriantoro (2000) state that complexity arises from weak ambiguity and structure, both in the main tasks and other tasks. On tasks that are confusing (ambigous) and unstructured, the alternative output is unpredictable. Chung and Monroe (2001) put forward the same argument, that the complexity of tasks in auditing is influenced by several factors, namely:

- The amount of information that is not relevant in the sense that the information is not consistent with the events that will be predicted;

- There is high ambiguity, namely the variety of outcomes (results) expected by the client from auditing activities.

Increased complexity in a task or system, will reduce the level of success of the task (Restuningdiah and Indriantoro, 2000). Regarding auditing activities, the high complexity of this audit can cause accountants to behave dysfunctionally, causing a decrease in auditor performance in making Audit judgements.

Professional Ethics of Accountants. The purpose of the establishment of the Accountant Professional Association is to guarantee the fulfillment of the highest 
professionalism standards for the performance of the kuntan with an orientation to the public interest. To achieve this goal, there are four basic needs that must be met by accountants (Proceedings of the IAI Congress VIII, 1998) namely:

- Credibility of information and information systems;

- Competence: for clear identification of the capacity of members of the profession concerned in the eyes of the client;

- Service Quality: to ensure that the professional services provided are based on high performance standards;

- Trust: to ensure that the professional services provided are based on a professional ethical framework.

In addition to these basic needs, there is an IAI Code of Ethics which consists of four parts, namely:

- Principle of Ethics: consists of professional responsibility, public interest, integrity, objectivity, competence and professional prudence, confidentiality, professional behavior, technical standards;

- Rules of Ethics: consist of independence, general standards of accounting principles, responsibilities to clients, responsibilities to colleagues, responsibilities and other practices;

- Interpretation of the Rules of Ethics;

- Questions and Answers.

The rules for implementing professional accounting ethics are regulated in Article 7 of the Indonesian Code of Accounting Ethics, which states that every accountant must live and practice the code of ethics with full responsibility and try to remind each other members of actions that are considered unethical.

Auditor Performance in Making Audit Judgement. Performance effectiveness refers to how well certain tasks are carried out in relation to criteria. For auditors, the quality of the work is estimated by looking at the accuracy of the answers given by the auditor for each audit task. Bonner and Sprinkle (2002) state that there are three variables that can affect performance, namely: person variables, task variables, and environmental variables. Person variables include attributes that a person has before performing tasks such as content knowledge, organizational knowledge, ability, self-confidence, cognitive style, intristic motivation, cultural values. Task variables include factors that vary both inside and outside the task, such as complexity, presentation format, processing and standby mode response. Meanwhile, environmental variables cover all conditions.

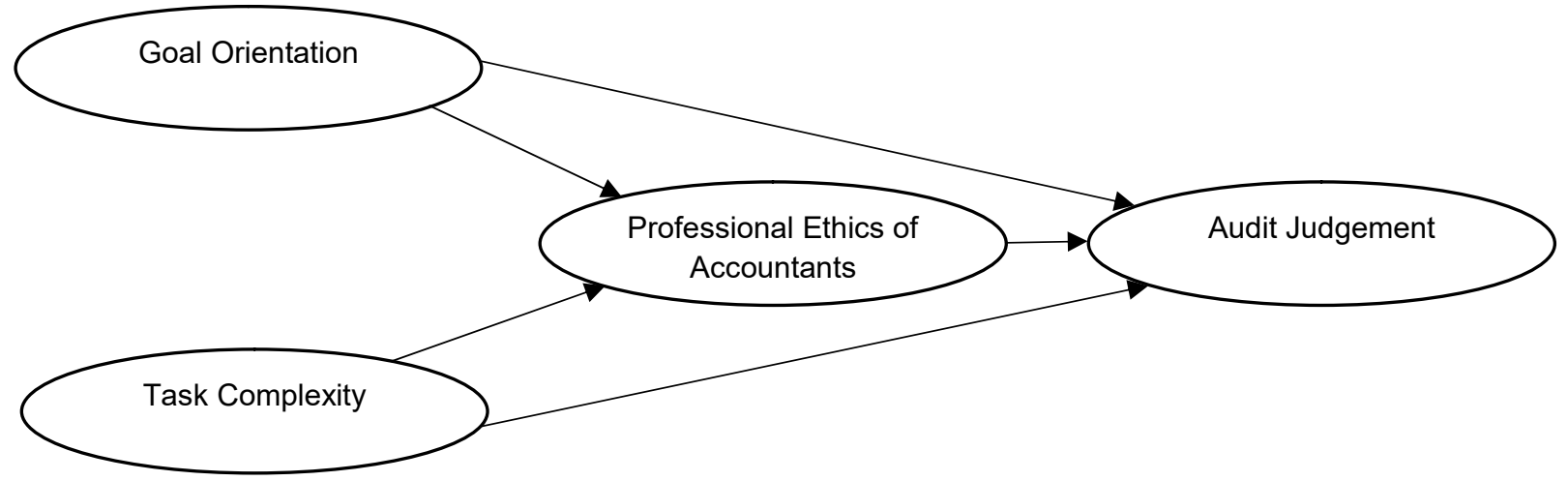

Figure 1 - Conceptual Framework

Conceptual Framework. The reason public accountants carry out audit activities is often the cause of the emergence of audit performance. Likewise the complexity of the tasks that surround the accountant in carrying out these tasks. Anyone who has an interest in the financial statements is the party that must be protected by the accountant's interests. As a result, the quality of audit judgement is often affected by the goal orientation and complexity 
of the auditor's duties. The influence can be positive or negative depending on the ethical morale of each auditor. Here is the importance of the Professional Ethics of Accountants who are believed to be able to intervene in the positive or negative effects of goal orientation and task complexity on audit judgement.

\section{METHODS OF RESEARCH}

The data obtained was analyzed using path analysis which was assisted by SPSS 23 software with a significance level of 0,05 . Data collection using a close-ended questionnaire distributed offline. In addition, documentation is also used to obtain information about the number of public accountants who work in KAP Surabaya with a work period of more than one year and have been in charge of the team (provide a Audit judgement) on the client's financial statements.

The population in this study was a Public Accountant who worked at KAP Surabaya. The sample is determined by purposive sampling, which is a Public Accountant who has provided a Audit judgement in one stage of examination and has worked more than one year. The total sample used amounted to 25 respondents. The KAP data as required in this study can be taken from the Instistut Indonesian Public Accountants or Instistut Akuntan Publik Indonesia (IAPI) website.

Operational Definition and Variable Measurement:

- Goal orientation is the auditor's preference in achieving the situation. This variable is measured by indicators: learning, performance-approach, and performanceavoidance.

- The complexity of the task is the difficulty of a task caused by limited capability, and memory and the ability to integrate problems that are owned by a decision maker. This variable is measured by indicators: the amount of information that is irrelevant and the existence of high ambiguity.

- Professional ethics is a set of rules that become benchmarks in carrying out their professional duties. This variable is measured by indicators: responsibility, integrity, objective, and independent.

- Audit judgement is the auditor's performance in determining opinions regarding the results of the audit which refers to the formation of an idea, opinion or estimate of an object of events, status, or other types of events. This variable is measured by indicators: content knowledge, organizational knowledge, self-confidence, cognitive style, intrinsic motivation, and cultural values

Based on the measurement of each of the variables above, the regression equations in this study are as follows:

- $Y_{\text {Ethics }}=b_{0}+b_{1}$ Orientation $+b_{2}$ Compleks $+e_{1}$

- $\mathrm{Y}_{\text {Judge }}=\mathrm{b}_{0}+\mathrm{b}_{1}$ Orientation $+\mathrm{b}_{2}$ Compleks $+\mathrm{b}_{3}$ Ethics $+\mathrm{e}_{2}$

\section{RESULT OF STUDY}

To test the mediation effect, testing must go through three criteria, namely: 1) the independent variable with the dependent variable must be significant, 2) the independent variable with the mediating variable must be significant, and 3) the mediating variable with the dependent variable must be significant (Baron and Kenny, 1986). This test begins by examining the relationship of the dependent variable (goal orientation and task complexity) to the mediating variable (professional ethics).

Table 1 - Testing of goal orientation and task complexity towards professional ethics

\begin{tabular}{|c|c|c|c|c|c|c|}
\hline & \multirow{2}{*}{ Model } & \multicolumn{2}{|c|}{ Unstandardized Coefficients } & \multirow{2}{*}{$\begin{array}{c}\text { Standardized Coefficients } \\
\text { Beta }\end{array}$} & \multirow{2}{*}{$t$} & \multirow{2}{*}{ Sig. } \\
\hline & & $\mathrm{B}$ & Std. Error & & & \\
\hline \multirow{3}{*}{1} & (Constant) & ,314 & ,016 & & 19,156 & 000 \\
\hline & Orientation & ,006 & ,002 & ,589 & 2,710 & 012 \\
\hline & Complex & ,021 & ,010 & ,464 & 2,137 &, 043 \\
\hline
\end{tabular}

a. Dependent Variable: Ethics 
Table 1 is the result of testing the goal orientation and the complexity of the task towards professional ethics. Goal orientation has a t-value of 2,710 and sig. 0,012. Task Complexity has a t-value of 2,137 and sig. 0,043. From the results of this test, it can be concluded that goal orientation and task complexity affect the professional ethics.

Table 2 - Testing goal orientation, task complexity, and professional ethics towards audit judgement

\begin{tabular}{|c|c|c|c|c|c|c|}
\hline & \multirow[t]{2}{*}{ Model } & \multicolumn{2}{|c|}{ Unstandardized Coefficients } & $\begin{array}{c}\text { Standardized } \\
\text { Coefficients }\end{array}$ & \multirow[t]{2}{*}{$t$} & \multirow[t]{2}{*}{ Sig. } \\
\hline & & $\mathrm{B}$ & Std. Error & Beta & & \\
\hline \multirow{4}{*}{1} & (Constant) & 6,378 & 1,692 & & 3,771 & ,000 \\
\hline & Orientation & 203 & ,063 & 301 & 2,840 & ,014 \\
\hline & Compleks & ,151 & ,049 & ,277 & 2,605 & ,019 \\
\hline & Ethics & , 167 & ,040 & ,412 & 4,212 &, 000 \\
\hline
\end{tabular}

a. Dependent Variable: Judge

Table 2 is the result of testing goal orientation, task complexity, and professional ethics on Audit judgementing. Table II shows the Goal orientation has a t-value of 2.840 and sig. 0.014 . Task Complexity has a t-value of 2.605 and sig. 0.019 . Professional ethics has a tvalue of 4.212 and sig. 0,000. This shows the influence between Goal orientation, Task Complexity, and Professional Ethics towards partial Audit judgements. From the results of this test, it can be concluded that goal orientation, task complexity, and professional ethics influence audit judgement.

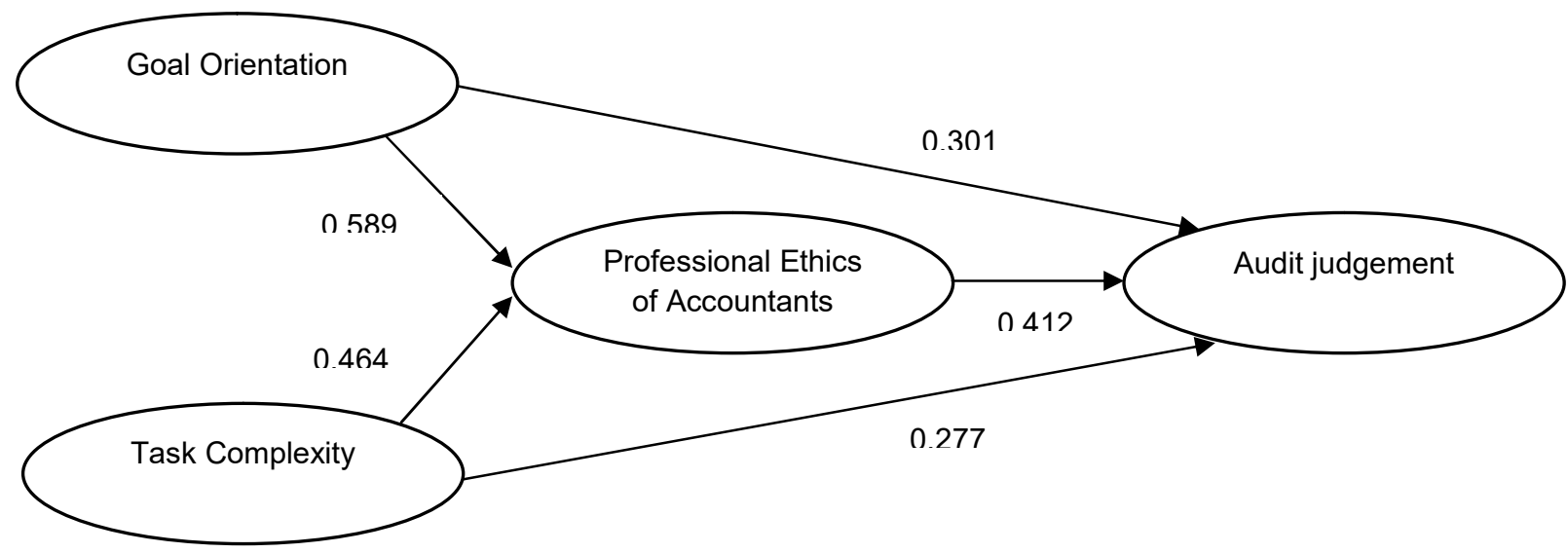

Figure 2 - Beta values for each variable

To find out the mediation effect, the test is continued by comparing the value of the direct and indirect effects of relations between variables (Figure 2 and Table 3). The Goal orientation variable has a direct effect on audit judgement of $0,091\left(0,301^{2}\right)$ and the indirect effect value is $0.243\left(0,589^{*} 0,412\right)$. Variable task complexity has a direct influence value of $0,077\left(0,277^{2}\right)$ and $0,191\left(0,464^{*} 0,412\right)$ for indirect effects. Based on this test, the indirect values for the two variables are greater, so it can be concluded that goal orientation and task complexity indirectly influence audit judgement through professional ethics.

Table 3 - Test Results of Direct and Indirect Influence of Orientation and Complexity on audit judgement $\mathrm{s}$ through Professional Ethics

\begin{tabular}{lccc}
\hline & Direct & Indirect & Total \\
\hline Orientation & 0,091 & 0,243 & 0,333 \\
Complexity & 0,077 & 0,191 & 0,268 \\
\hline
\end{tabular}

\section{DISCUSSION OF RESULTS}

Effect of Orientation Objectives on Audit Judgement. The results of the study indicate the influence of goal orientation on audit judgements. These results support previous studies 
such as Sanusi et al. (2007) who found that goal orientation influences performance, including academic performance, task performance (Bell and Kozlowski, 2002), sales performance (Vande Walle et al., 1999), and job performance (Janssen and Van Yperen, 2004). A recent meta-analysis also found that the characteristics of learning objectives were significantly related to learning performance and the orientation section of learning objectives was related to job performance (Payne et al., 2007). In the accounting environment, a study found management accountants with orientation learning to be more likely to be involved in management decision processes (Coad, 1999).

Goal orientation has a beneficial influence on performance, and this opinion is supported by theory and empirical evidence. Theoretically, because people with goal orientation, especially learning, will focus on developing competencies, they have intrinsic interest in the tasks they perform (Barron and Harackiewicz, 2001), therefore, they will be more involved in the task than they are who don't have that orientation. In addition, people with a tendency to develop their competencies will devote more resources (eg attention, effort, perseverance) and use them more effectively, using elaborative strategies in carrying out their duties than those who are not so concerned about demonstrating competency. them (Dweck and Leggett, 1988). Even when faced with a difficult task, people who have a goal orientation will respond with increased effort, perseverance, and strategy because they tend to see tasks as challenges and opportunities for growth and self-development (Vande Walle et al., 2001). Greater effort, perseverance, and using effective strategies generally lead to higher performance (Bandura, 1993; Locke and Latham, 1990).

Effect of Task Complexity on Audit Judgement. The results of the study indicate the influence of the task complexity on Audit judgementing. These results support the research of Chung and Monroe (2001) saying that high task complexity influences judgement taken by auditors. The auditor feels that the audit task he is facing is a complex task so that the auditor has difficulty in performing tasks and cannot make professional judgement. The same thing was also shown in Wijayatri (2010) which explained that task complexity had the most dominant influence on audit judgement. As a result, the judgement taken by the auditor is not in accordance with the evidence obtained.

In the audit environment, task complexity is an important factor that can affect the performance of Audit judgements. When the auditor is faced with a task with high complexity, he will have difficulty in completing his task so that he is unable to integrate information into a good judgement. The goal setting theory explains that auditors who do not know the purpose and purpose of the task will also experience difficulties when faced with a complex task. The auditor does not know what goals he must achieve in carrying out his duties so that it can affect the accuracy of the judgement he takes.

Intervention of Professional Ethics in the Effect of Goal orientation and Task Complexity on Audit Judgement. The results of the study indicate that there is an indirect influence on the relationship of goal orientation and complexity of the task to audit judgement through professional ethics. Professional ethics relates to how auditor compliance with auditor professional standards or professional standards of public accountants (SPAP). Professional code of ethics is one of the efforts of a professional association to maintain the integrity of the profession in order to be able to face various pressures that can arise from him or outside parties. Research by Suraida (2005) examines showing professional ethics has an effect on the accuracy of giving public accountant opinion results that professional ethics has an influence on giving audit opinion.

Every public accountant is also expected to hold on to the professional ethics set by IAPI, so that an unfair competition situation can be avoided. Without ethics, the accounting profession will not exist because the accounting function is the provider of information for the process of making business decisions by business people. By upholding professional ethics, it is expected that fraud will not occur among public accountants, so that it can provide audit opinions that are truly in accordance with the financial statements presented by the company. 


\section{CONCLUSION AND SUGGESTIONS}

Goal orientation has a beneficial influence on the performance of audit judgements. Those who have a goal orientation, especially learning, will focus on developing competencies, they have an intrinsic interest in the tasks they do. Greater efforts, perseverance, and using effective strategies generally lead to higher performance. When the auditor is faced with a task with high complexity, he will have difficulty in completing his task so that he is unable to integrate information into good judgement. Auditors who do not know the purpose and purpose of their duties will also experience difficulties when faced with a complex task. Every public accountant is expected to hold firm to the professional ethics established by IAPI, so that an unfair competition situation can be avoided. Without ethics, the accounting profession will not exist because the accounting function is the provider of information for the process of making business decisions by business people. By upholding professional ethics, it is expected that fraud will not occur among public accountants, so that it can provide audit opinions that are truly in accordance with the financial statements presented by the company. Suggestions that can be given from this study are: 1) for auditors, it is expected that auditors always adhering to professional ethics so that auditors can make judgement professionally; 2) for the next researcher, it is expected that this research can be developed using an experimental method so that the differences in respondent's treatment can be clearly seen, and examine aspects that influence other auditor judgement s that have not been studied in this study, such as training and different cultures, by further expanding the research sample.

\section{REFERENCES}

1. Arlow, P, 1991, Personal Characteristics in College Student : Evaluation of Business Ethics and Corporate Social Responsibility, Journal of Business Ethics, Vol. 10, pp. 63-69

2. Agoes, S., dan Ardana, C., 2009, Etika Bisnis dan Profesi - Tantangan Membangun Manusia Seutuhnya, Salemba Empat, Jakarta.

3. Alleyne, P., Devonish, D., Nurse, J., 2006, Perception of Moral Intensity Among Undergraduate Accounting Students in Barbados, Journal of Eastern Carribean Studies, Vo. 31, No. 3, pp 1-26.

4. Bandura, A. 1986. Social Foundations of Thought and Action: A Social Cognitive Theory. Englewood Cliffs, NJ: Prentice-Hall.

5. Baron, R. M., \& Kenny, D. A. 1986. The Moderator-Mediator Variable Distinction in Social Psychological Research: Conceptual, Strategic, and Statistical Considerations. Journal of Personality and Social Psychology, 51(6), 1173-1182.

6. Barron, K. E. and Harackiewicz, J. M. (2001). Achievement Goals and Optimal Motivation: Testing Multiple Goal Models. Journal of Personality and Social Psychology, 80: 706-722.

7. Bachtiar, Emil, 2012, Kasus-Kasus Etika Bisnis dan Profesi, Salemba Empat, Jakarta

8. Bell, B. S. and Kozlowski, S. W. 2002. Goal Orientation and Ability: Interactive Effects on Self-efficacy, Performance, and Knowledge. Journal of Applied Psychology, 87: 497-505.

9. Buchan, HF, 2005, Ethical Decision Making in Public in the Public Accounting Profesion : an Extension of Ajzen's Theory of Planned Behavior, Journal of Business Ethics, Vol. 61 No. 2, pp. 165-181.

10. Charles, Handy, 2002, What a Business For?, Harvard Business Review.

11. Cohen, JR., and Bennie, N.M, 2006, The Applicability of a Contingent Factors Model to Accounting Ethics Research, Journal of Business Ethics, Vol. 68 pp. 1-18.

12. Chung, J. and Monroe, G. S. 2001. A Research Note on the Effects of Gender and Task Complexity on an Audit judgement. Behavioral Research in Accounting, 13: 111-125.

13. Coad, A. F. 1999. Some Survey Evidence on the Learning and Performance Orientations of Management Accountants. Management Accounting Research, 10: 109-135. 
14. Dwyer, P.D.,Welker, R.B, and Friedberg, A.H, 2000, A Research Note Concerning the Dimensionality of the Professional Commitment Scale, Behavioral Research in Accounting, Vol. 12.

15. Elliot, A. J. and Church, M. A. 1997. A Hierarchical Model of Approach and Avoidance Achievement Motivation, Journal of Personality and Social Psychology, 72: 218-232.

16. Febriyanti, 2011, Perkembangan Model Moral Kognitif dan Relevansinya dalam RisetRiset Akuntansi, Jurnal Ekonomi dan Informasi Akuntansi (JENIUS), Vol. 1, No.1, Januari 2011, hal 57-77.

17. Fischer, M, dan Rosenzweig, K, 1995, Attitudes of Student and Accounting Practitioners Concerning the Ethical Acceptability of Earning Management, Journal of Business Ethics, Vol. 14, No. 6, pp 433-444.

18. Ghozali, Imam. 2001, Aplikasi Analisis Multivariate Dengan Program SPSS. Badan Penerbit Universitas Diponegoro, Semarang.

19. Harahap, S.S, 2008, Pentingnya Unsur Etika dalam Profesi Akuntan dan Bagaimana di Indonesia, Ekonomi Islam (online), diakses 20 Januari 2013.

20. Ikatan Akuntan Indonesia, 1998, Kode Etik Akuntan Indonesia, Prosiding Kongres VIII IAI, Lampiran 2.

21. Ilyas, M., Herliyansyah,Y. dan Muslim S, 2007, Peran Pernyataan Orientasi Tujuan (State Goal Orientation) dalam Pengajaran di Kelas terhadap Proses Pencapaian Kinerja Mahasiswa Akuntansi di Perguruan Tinggi, Simposium Nasional Akuntansi X Unhas Makassar.

22. Janssen, O. and Van Yperen, N. W. 2004. Employees' Goal Orientations, the Quality of Leader-member Exchange, and the Outcomes of Job Performance and Job Satisfaction. Academy of Management Journal, 47: 368-384.

23. Jiambalvo, J. dan Pratt, J. 1982. Task Complexity and Leadership Effectiveness in CPA Firms, The Accounting Review, Vol LVII, No.4.

24. Johnson, D.S., Beauregard, R.S., Hoover, P.B., and Schmidt, A.M. 2000. Goal Orientation and Task demand Effects on motivation, Affect, and Performance. Journal of Applied Psychology, Vol. 85, No. 5, 724-738.

25. Kanfer, R. and Ackerman, P. L. 1989. Motivation and Cognitive Abilities: An Integrative/Aptitude-treatment Approach to Skill Acquisition. Journal of Applied Psychology Monograph, 74: 657-690.

26. Karcher, J.N., 1996, Auditirs, Ability to Discern the Presence of Ethical Problems, Journal of Business Ethics, Vol. 15 No. 10, pp. 33-50.

27. Khomsiyah dan Indiantoro N., 1998, Pengaruh Orientasi Etika terhadap Komitmen dan Sensitivitas Etika Auditor Pemerintah di DKI Jakarta, Jurnal Riset Akuntansi Indonesia, Vol. 1, No. 1, hal 13-28.

28. Kaudin A., dan Inggarwati K., 2010, Persepsi Etis Pelaku Akuntansi terhadap Praktek Manajemen Laba Berdasarkan Profesi Akuntansi dan Jender, Jurnal Manajemen Teori dan Terapan, Fakultas Ekonomi Universitas Islam Indonesia, Tahun 3, No, 3, hal 1-15

29. Kleiner C, and Lord, M, 1999, The Cheating Game, U.S. News and World Report, pp. 5463.

30. Leung, P., and Cooper BJ., 1995, Ethical Dilemmas in Accountancy Practice, Australian Accountant, May, pp. 28-32.

31. Locke, E. A. and Latham, G. P. 1990. A Theory of Goal Setting and Task Performance. Englewood Cliffs, NJ: Prentice-Hall.

32. Nurwanah, A., 2008, Dilema Etika Profesi Akuntan dalam Mempertahankan Krdibilitasnya, Jurnal Ichsan Gorontalo, Vol 3, No. 2, hal 1615-1629.

33. O'Leary, C., and Cotter, D., 2000, The Ethics of Final Year Accountancy Students : an International Comparison, Managerial Auditing Journal, 15/3 ; pp 108-115.

34. Payne, S. C., Youngcourt, S. S. and Beaubien, J. M. 2007. A Meta-analytic Examination of the Goal Orientation Nomological Net. Journal of Applied Psychology, 92: 128-150.

35. Ponemon, L., and D. Gabhart, 1993, Ethical Reasoning in Accounting and Auditing, Journal of Business Ethics, Vol. 9, pp. 639-653. 
36. Rest, JR, 1983, Morality, in Handbook of Child Psychology, Vol. III (4th ed.), P.H. Mussen (series ed.), J.H. Flavell and E.M. Markman (volume eds.), John Wiley \& Sons, New York. Pp. 556-629.

37. Sanusi, ZM, Iskandar, TM dan June M. L. Poon. 2007. Effect of Goal Orientation and Task Complexity on Audit judgement Performance, Malaysian Accounting Review. pp. 123-139.

38. Suraida. (2005). Uji Model Etika, Kompetensi, Pengalaman Audit dan Resiko Audit Terhadap Skeptisisme Profesional Auditor. Jurnal Akuntansi. Th IX/02/Mei.

39. Shaub, M.K., Finn, DW, and Munter, P., 1993, The Effect of Auditor Ethical Orientation on Commitment and Ethical Sencitivity, Behavioral Research in Accounting, Vol. 5, pp 145-169.

40. Spain, JW., Brewer, P., dan Garner, SJ., 2002, Ethics and Geography - Impact of Geographical Cutural Differences on Students Ethical Decision, Journal of Business Ethics, Vol. 41, pp 187-194.

41. VandeWalle, D. 2001. Goal Orientation: Why Wanting to Look Successful doesn't Always Lead to Success. Organizational Dynamics, 30: 162-171.

42. Volker, J.M., 1984, Counseling Experince, Moral Judgement, Awareness of consequnces, and Moral Sensivity in Conseling Practice, Unpublished Doctoral Desertation, Minneapolis, MN : University of Minnesota Press.

43. Wijayatri, Astri. 2010. Pengaruh Tekanan Ketaatan, Kompleksitas Tugas dan Keahlian Audit terhadap Audit judgement (Studi Empiris pada Kantor Akuntan Publik di Surabaya). Skripsi. Yogyakarta: Universitas Pembangunan Nasional.

44. Wilopo, 2006, Analisis Faktor-Faktor yang Berpengaruh terhadap Kecenderungan Kecurangan Akuntansi - Studi Kasus pada Perusahaan Publik dan Badan Usaha Milik Negara di Indonesia, Jurnal Riset Akuntansi Indonesia, STIE Perbanas Surabaya, Vol 9, No. 3, hal 346-366.

45. Zweig, D. and Webster, J. 2004. What are We Measuring? An Examination of the Relationships between the Big-five Personality Traits, Goal Orientation, and Performance Intentions. Personality and Individual Differences, 36: 1693-1708. 